\title{
Comparison of Fermentation Kinetics (in vitro) of Napier Grass and Fruit Peels for Ruminants: The Pattern of Organic Matter Degradability, Volatile Fatty Acids Concentration, Estimated Methane and Microbial Biomass Production
}

\author{
* M.I. Okoruwa and F.U. Igene. \\ Department of Animal Science, Ambrose Alli University, P.M.B. 14, Ekpoma, Edo State,Nigeria.
}

\begin{abstract}
The study was conducted to determine the pattern of organic matter degradability, volatile fatty acid concentration, estimated methane and microbial protein products of napier grass and fruit peels when fermented in the rumen. In vitro method was used to determine the pattern of these end-products. Five experimental samples were randomly assigned to five treatments with one sample per treatment in a completely randomized design. The compared experimental samples were napier grass $(N G)$, orange peel $(O P)$, pawpaw peel $(P P L)$, mango peel $(M P)$ and plantain peel $(P P)$. Results obtained showed that parameters observed under in vitro gas production characteristics, organic matter degradation, volatile fatty acids concentration, estimated methane and microbial protein products were significantly $(P<0.05)$ affected with the exception of intercept $(a)$ and gas production rate constant for the insoluble fraction $(b)(P<0.05)$. The incubation time $\left(t^{1} / 2\right)(18.00 \mathrm{hr})$, acetate $(74.42 \%)$ and methane $(38.00 \mathrm{mmol})$ were significantly $(P<0.05)$ highest for NG. Gas production from the insoluble but degradable fraction $(58.98 \mathrm{ml})$, potential gas production $(62.00 \mathrm{ml})$ and propionate $(13.42 \%)$ were significantly $(P<0.05)$ higher for PPL whereas organic matter degraded $(42.01 \mathrm{mg})$, volatile fatty acid concentration (72.75 mmol/litre), butyrate (10.20\%) and microbial protein (2393g) were better for MP. It was concluded that MP and PP have the potentials to improve rumen fermentation efficiency and reduce methane gas.
\end{abstract}

Keywords:Napier grass, fruit peels, organic matter, volatile fatty acids, methane, microbial protein.

\section{Introduction}

Small ruminants are important animal resources in the tropics, where they play a predominant role in the sustenance of the livelihoods of impoverished families especially in the rural areas. In Nigeria, they represent about $63.70 \%$ of the total grazing domestic animals (Yakubu et al., 2010). The adaptive features of sheep and goats such as feeding behaviour, disease and remarkable capacity from drought enable them to cope effectively with a variety of stressful tropical environmental conditions (Helal et al., 2010). Feed resources for ruminant livestock in the tropics are natural pastures which are limited in supply during the dry season. Bayble et al. (2007) observed that dry season feeding of napier grass(Pennisetum purpureum) to ruminants had always been a constant problem to livestock farmers as their supplies are limited both in quantity and quality, which make ruminants faced with problems of meeting their nutritional requirements in the tropics.

With increasing the production of fruits such as pawpaw, mango, orange and plantain from farms in southern Nigeria, there is an overabundant supply of peels generated from their processing. Only a small portion of these peels are used as feed for livestock. The rest are thrown away and piled up, rotten with foul smell as a result of fermentation and putrefaction processes by microbes and thereby constituting a nuisance as they pollute the environment. In recent times, research has gone a step further into the use of peels in ruminant nutrition. Fruit peels could contribute to diets of ruminant livestock in Nigeria, if properly harnessed and processed. They could be used as a major source of dietary nutrients and energy which account for the entire non-forage portion of the diet in ruminant production, since they contain little economical value as edible foods for human consumption (Omole et al., 2004). In Nigeria, little research has been done to characterise fruit peels for nutrient contents and evaluate them as potential feed resources, since variability exist in chemical composition of fruit peels.

Cumulative gas production from the incubation of feedstuffs using rumen liquor suspension as inoculum in vitro together with crude nutrient composition can be used to predict organic matter digestibility, volatile fatty acid (VFA) concentration, methane and microbial biomass production of ruminant feeds with high accuracy (Aregheare and Abdulrazak, 2005). The proportion of major partials of VFA acid concentration namely acetate, propionate and butyrate in the rumen depends largely on the type of feed consumed by the ruminant in particular, the fractions contained in the feed. Fermentation of a feed containing a large cell wall is likely to produce a higher molar proportion of acetate and a lower proportion of propionate. For feed ingredients in which cell content is high while the cell wall is low, rumen fermentation would be 
expected to result in a reduction of molar proportion of acetate and an increase of molar proportion of propionate (Widiawati and Thalib, 2009). The synthesis of acetate in the rumen results in an increase of hydrogen production. These results in an increase of methanogenic bacteria activities which use the hydrogen and $\mathrm{CO}_{2}$ produced to synthesize methane (Adeyosoye et al., 2010). The $\mathrm{CO}_{2}$ produced from carbohydrate fermentation may contribute about $40 \%$ of total gas resulted in the rumen (McDonald et al., 2002). Therefore a feed containing a large amount of carbohydrate should produce more gas than that having less carbohydrate.

This study was therefore conducted with the objectives of assessing the differences in both partial and total organic matter digestibility, concentration of VFA, namely; acetate, propionate and butyrate, $\mathrm{CH}_{4}$ microbial and protein production of napier grass and fruit peels.

\section{Materials and Methods}

\section{Description of Site and Samples Collection}

The research was conducted at the Teaching and Research Farm of Ambrose Alli University, Ekpoma, Nigeria (Long $6.09^{0} \mathrm{E}$ and Lat. $6.42^{\circ} \mathrm{N}$ ). The area has an average annual rainfall of $1556 \mathrm{~mm}$ with an annual temperature range between $26^{\circ} \mathrm{C}$ and $34^{\circ} \mathrm{C}$.

Fresh napier grass was harvested from the pasture land within the Teaching and Research Farm. Fruit peels (orange, pawpaw, mango and plantain) were collected from their processing points located and sun-dried within Ekpoma.

\section{Sample Preparation and Chemical Analysis}

About $500 \mathrm{~g}$ of each sample was oven dried at $105^{\circ} \mathrm{C}$ for $24 \mathrm{hrs}$, cooled and weighed and then milled to pass through a $1 \mathrm{~mm}$ screen. Each milled sample was stored in an air tight bottle at $4^{0} \mathrm{C}$ before being analyzed for proximate composition according to AOAC (1990) procedures. Neutral and acid detergent fibre were determined as described in Van Soest et al. (1991).

\section{Experimental Design}

Five samples; napier grass and peels of fruits (orange, pawpaw, mango and plantain) were randomly allotted to five treatment groups of three (3) replicates each, in a completely randomized design.

\section{In Vitro Study}

Fermentation kinetics (in vitro) gas production was carried out using the napier grass, orange, pawpaw, mango and plantain peels as the standard feed substrates. About $200 \mathrm{mg}$ of dry milled samples of the five treatments were replicated three times for each treatment. Microbial inoculum was derived from fluid taken from five herds of West Africa Dwarf Sheep (WAD). The method of collection was as described by Babayemi and Bamikole (2006) using suction tube from WAD sheep previously fed $60 \%$ napier grass and $40 \%$ concentrate feeds (29\% wheat offal, $16 \%$ brewery dried grain, $10 \%$ orange peel, $10 \%$ pawpaw peel, $10 \%$ mango peel, $10 \%$ plantain peel, $7 \%$ groundnut husk, $6 \%$ cowpea husk, $0.75 \%$ limestone, $0.5 \%$ dicalcium phosphate, $0.5 \%$ salt and $0.25 \%$ vitamin premix) at $5 \%$ body weight. The composition of the mixed diet was designed to provide a crude protein $(\mathrm{CP})$ content of above $13 \%$ on a dry matter basis. This level of $\mathrm{CP}$ is recommended for maintenance of tropical sheep (Widiawati and Thalib, 2009). The inoculum was collected at 3 hours after being considered to be a maximum activity (Camero and Franco, 2001). Incubation procedure was as reported by Menk and Steingass (1988) using 100ml calibrated transparent plastic syringes with fitted silicon tube. Each of the samples was carefully dropped into syringes and thereafter, $30 \mathrm{ml}$ inoculum containing cheese cloth strained rumen liquor and buffer. The syringe was trapped and pushed upward by the piston in order to completely eliminate air in the inoculum. The silicon tube in the syringe was then tightened by a metal clip so as to prevent escape of gas. Incubation was carried out at $39^{\circ} \mathrm{C}$ and the volume of gas production was measured at 3, 6, 9, 12, $15,18,21$ and $24 \mathrm{hrs}$.

\section{Sampling and Recording}

Gas production: At post incubation period, the average volume of gas produced from the blank was deducted from the volume of gas produced per sample against incubation time and from the graph, the gas production characteristics were estimated.

Organic matter degradation: The feed organic matter degradation was determined by vacuum filtration through a pre-weighed crucible. The crucibles containing feed residues were dried in an oven at $105^{\circ} \mathrm{C}$ for 24 hours or to constant weight to determine the DM content, then ashed in a muffle furnace at $500^{\circ} \mathrm{C}$ for 6 hours for determination. Organic matter was calculated by subtracting ash from dry matter.

VFA concentration: Each experimental sample of $5 \mathrm{ml}$ liquor of the medium was transferred into a $m l$ plastic storage vial for the determination of VFA concentration. The concentration of acetate, propionate and butyrate in each sample was determined using gas liquid chromatography (Vasta et al., 2009). 


\section{Calculation}

The gas production characteristics were estimated using the equation $Y=a+b\left(1-e^{-c t}\right)$ as described by Babayemi and Bamikole (2006).

Where: $\mathrm{Y}=$ volume of gas produced at time $\mathrm{t}$.

$$
\begin{aligned}
& \mathrm{a}=\text { intercept } \\
& \mathrm{b}=\text { gas production from the insoluble but degradable }
\end{aligned}
$$

fraction

fraction (b)

$$
\mathrm{c}=\text { gas production rate constant for the insoluble }
$$

$$
\begin{aligned}
& t \frac{1}{2}=\text { incubation time } \\
& a+b=\text { potential gas production }
\end{aligned}
$$

The amount of organic matter degraded was calculated by subtracting the organic matter in feed sample by organic matter in residue in each incubation bottle.

VFA concentration in the solution from each bottle was calculated based on the peak of the graph recorded from the gas liquid chromatography, using the equation as described by Widiawati and Thalib (2009).

$$
V F A(\text { mmoel })=\left(P_{s p l} / P_{s t d}\right) \times\left(V F A_{s t d}\right)
$$

Where:

$P_{s p l}=$ height $(\mathrm{mm})$ of the graph recorded when the sample was read by gas liquid chromatography.

$P_{s t d}=$ height $(\mathrm{mm})$ of the graph recorded when the VFA standard was read by gas liquid chromatography.

$V F A_{s t d}=$ concentration (mmol) of VFA of the standard solution.

Methane produced during fermentation of the feeds in the culture bottles was estimated using the equation based on VFA proportions, described by Widiawati and Thalib (2009).

$$
\mathrm{CH}_{4}=0.5 \times(A)+0.5 \times(B)-0.25 \times(P) .
$$

Where: $\mathrm{CH}_{4}=$ amount $(\mathrm{mmol})$ of methane produced

$$
\begin{aligned}
& (A)=\text { concentration }(\mathrm{mmol}) \text { of acetate } \\
& (B)=\text { concentration }(\mathrm{mmol}) \text { of butyrate } \\
& (P)=\text { concentration }(\mathrm{mmol}) \text { of propionate. }
\end{aligned}
$$

Widiawati and Thalib (2009), suggested that microbial protein synthesized in the rumen from carbohydrate fermentation might be predicted from the values of ATP produced and the values of ATP required for synthesis of a unit of microbial cell. The values of ATP could be estimated from the concentration of the VFA using the equation according to Widiawati and Thalib (2009).

$$
A T P_{p r}=2.5 \times(A)+2.75 \times(P)+3.5 \times(B) \text {. }
$$

Where; $A T P_{p r}=$ amount $(\mathrm{mol})$ of ATP produced

With the assumption that each mole of ATP produced 10g of microbial cell (Widiawati and Thalib, 2009). Hence, microbial mass can be calculated with the following equation.

Microbial mass $=10 \times A T P_{p r}$

Where microbial mass is the amount $(\mathrm{g})$ of microbial cell produced.

Statistical Analysis

All the data obtained were subjected to one-way analysis of variance (ANOVA). Significant differences between means were separated by Duncan Multiple Range Test (SAS, 1999).

\section{Chemical Composition of the Experimental Feedstuffs}

\section{Results and Discussions}

The chemical composition of the experimental feedstuffs (\% DM basis) is shown in Table 1. The result showed that napier grass and fruit peels had relatively high dry matter (DM) contents, which range in values from 66.34 to $87.65 \%$. This indicates that the napier gras and fruit peels can be stored for a period of time without spoilage as well as not being susceptible to microbial growth.

The crude protein $(\mathrm{CP})$ values ranged from $7.53 \%$ in orange peel to $9.12 \%$ in mango peel. The $\mathrm{CP}$ values obtained in this study, were within the $7-9.5 \%$ CP moderate level recommended by Bengaly et al. 
(2007) for minimum growth in ruminant animals. Thus the napier grass and fruit peels would provide adequate nitrogen requirement by rumen microbes to maximum digest the components of dietary fibre leading to the production of volatile fatty acids (Lamidi et al., 2010). Ether extract had similar low contents with the exception of orange peels $(5.64 \%)$. The crude fibre $(\mathrm{CF})$ and ash contents were considerably different, being highest in napier grass $(29.55 \%$ and $10.95 \%$ and lowest in mango peel (5.24\% and $2.34 \%)$ respectively. This implies that the total crude fibre and mineral present in napier grass is higher compared with fruit peels. Nitrogen free extract values that range from $50.24 \%$ in napier grass to $82.88 \%$ in mango peel is considerable in amount and that indicates high carbohydrate content in the feedstuffs. Napier grass contain high crude fibre fraction as indicated by higher neutral detergent fibre $(69.02 \%)$ and acid detergent fibre $(46.79 \%)$ values compared to corresponding values of fruit peels. The chemical composition values of napier grass and fruit peels obtained in this finding were slightly lower than those reported by Omole et al. (2004). This marked differences between the values obtained in this finding and those reported in literatures might have been caused by differences in genetic origin, soil fertility and time of harvesting of the grass and fruits.

\section{In Vitro Gas Production Characteristics}

The in vitro gas production characteristics of the napier grass and fruit peels are presented in Table 2. The results showed that in vitro gas production characteristics at 24 hours after incubation differed significantly $(\mathrm{P}<0.05)$ for all the parameters assessed except intercept (c) that were not significant $(\mathrm{P}>0.05)$ affected.

Table 1: Chemical composition (\% DM basis) of napier grass and fruit peels used in the experiment.

\begin{tabular}{|c|c|c|c|c|c|}
\hline Nutrient & $\begin{array}{l}\text { Napier grass } \\
\quad \text { (NG) }\end{array}$ & $\begin{array}{l}\text { Orange peel } \\
(\text { OP) }\end{array}$ & $\begin{array}{c}\text { Pawpaw peel } \\
\text { (PPL) }\end{array}$ & $\begin{array}{l}\text { Mango peel } \\
\text { (MP) }\end{array}$ & $\begin{array}{c}\text { Plantain peel } \\
\text { (PP) }\end{array}$ \\
\hline Dry matter (DM) & 87.65 & 78.32 & 66.34 & 72.01 & 75.67 \\
\hline Ether extract (EE) & 1.15 & 5.64 & 0.49 & 0.42 & 1.24 \\
\hline Ash & 10.95 & 6.75 & 4.61 & 2.34 & 5.62 \\
\hline Nitrogen free extract (NFE) & 50.24 & 55.43 & 79.07 & 82.88 & 79.51 \\
\hline Neutral detergent fibre (NDF) & 69.02 & 62.17 & 42.03 & 35.12 & 33.17 \\
\hline $\begin{array}{l}\text { Acid detergent fibre } \\
\text { (ADF) }\end{array}$ & 46.79 & 32.00 & 11.37 & 10.13 & 9.93 \\
\hline
\end{tabular}

Table 2: In vitro gas production characteristics of napier grass and fruit peels $(\mathrm{ml} / 200 \mathrm{mgDM})$ in rumen fluid of sheep fed napier grass supplemented with concentrated diet (24 hours).

\begin{tabular}{|c|c|c|c|c|c|c|}
\hline Nutrient & $\begin{array}{l}\text { Napier grass } \\
\text { (NG) }\end{array}$ & $\begin{array}{c}\text { Orange peel } \\
\text { (OP) }\end{array}$ & $\begin{array}{c}\text { Pawpaw peel } \\
\text { (PPL) }\end{array}$ & $\begin{array}{c}\text { Mango peel } \\
\text { (MP) }\end{array}$ & $\begin{array}{c}\text { Plantain peel } \\
\text { (PP) }\end{array}$ & SEM \pm \\
\hline $\mathrm{a}(\mathrm{ml})$ & 3.00 & 3.52 & 3.02 & $4.50^{\mathrm{a}}$ & 3.00 & 0.25 \\
\hline $\mathrm{b}(\mathrm{ml})$ & $27.00^{c}$ & $41.48^{\mathrm{b}}$ & $58.98^{\mathrm{a}}$ & $53.50^{\mathrm{a}}$ & $34.00^{\mathrm{b}}$ & 1.92 \\
\hline $\mathrm{a}+\mathrm{b}(\mathrm{ml})$ & $30.00^{\mathrm{c}}$ & $45.00^{\mathrm{b}}$ & $62.00^{\mathrm{a}}$ & $58.00^{\mathrm{a}}$ & $37.00^{\mathrm{b}}$ & 2.01 \\
\hline $\mathrm{C}\left(\mathrm{mlh}^{-1}\right)$ & 0.06 & 0.05 & 0.06 & 0.05 & 0.07 & 0.03 \\
\hline $\mathrm{t}^{1} / 2(\mathrm{hr})$ & $18.00^{\mathrm{a}}$ & $17.50^{\mathrm{b}}$ & $15.26^{\mathrm{c}}$ & $14.65^{\mathrm{c}}$ & $17.86^{\mathrm{b}}$ & 0.67 \\
\hline
\end{tabular}

a, b, c means on the same row with different superscripts are significantly different $(\mathrm{P}<0.05), \mathrm{SEM}=\mathrm{Standard}$ error of mean. 
Table 3: Organic matter degraded, volatile fatty acids concentration and estimated methane production of napier grass and fruit peels at 24 hours of incubation.

\begin{tabular}{|c|c|c|c|c|c|c|}
\hline Nutrient & $\begin{array}{l}\text { Napier grass } \\
\text { (NG) }\end{array}$ & $\begin{array}{l}\text { Orange peel } \\
\text { (OP) }\end{array}$ & $\begin{array}{c}\text { Pawpaw peel } \\
\text { (PPL) }\end{array}$ & $\begin{array}{l}\text { Mango peel } \\
\text { (MP) }\end{array}$ & $\begin{array}{c}\text { Plantain peel } \\
\text { (PP) }\end{array}$ & SEM \pm \\
\hline Organic matter (mg) & $32.04^{\mathrm{c}}$ & $36.76^{\mathrm{b}}$ & $38.76^{\mathrm{b}}$ & $42.01^{\mathrm{a}}$ & $40.99^{\mathrm{a}}$ & 1.66 \\
\hline $\begin{array}{l}\text { Volatile fatty acid } \\
\text { (mmol/litre) }\end{array}$ & $48.54^{\mathrm{c}}$ & $50.10^{\mathrm{b}}$ & $70.92^{\mathrm{a}}$ & $72.75^{\mathrm{a}}$ & $71.22^{\mathrm{a}}$ & 2.09 \\
\hline \multicolumn{7}{|l|}{ Molar \% } \\
\hline Acetate & $74.42^{\mathrm{a}}$ & $68.93^{\mathrm{b}}$ & $65.90^{\mathrm{b}}$ & $67.52^{\mathrm{b}}$ & $66.23^{\mathrm{b}}$ & 2.06 \\
\hline Propionate & $9.35^{\mathrm{b}}$ & $10.62^{\mathrm{a}}$ & $13.42^{\mathrm{a}}$ & $12.66^{\mathrm{a}}$ & $13.09^{\mathrm{a}}$ & 0.68 \\
\hline Butyrate & $6.43^{\mathrm{b}}$ & $7.01^{\mathrm{b}}$ & $8.70^{\mathrm{a}}$ & $10.20^{\mathrm{a}}$ & $9.60^{\mathrm{a}}$ & 0.56 \\
\hline Methane (mmol) & $38.00^{\mathrm{a}}$ & $36.00^{\mathrm{b}}$ & $34.00^{\mathrm{b}}$ & $35.00^{\mathrm{b}}$ & $35.02^{\mathrm{b}}$ & 0.94 \\
\hline
\end{tabular}

a, b, c means on the same row with different superscripts are significantly different $(\mathrm{P}<0.05), \mathrm{SEM}=$ standard error of means.

Figure 1: Estimation of microbial protein produced for napier grass and fruit peels at 24 hours of incubation.

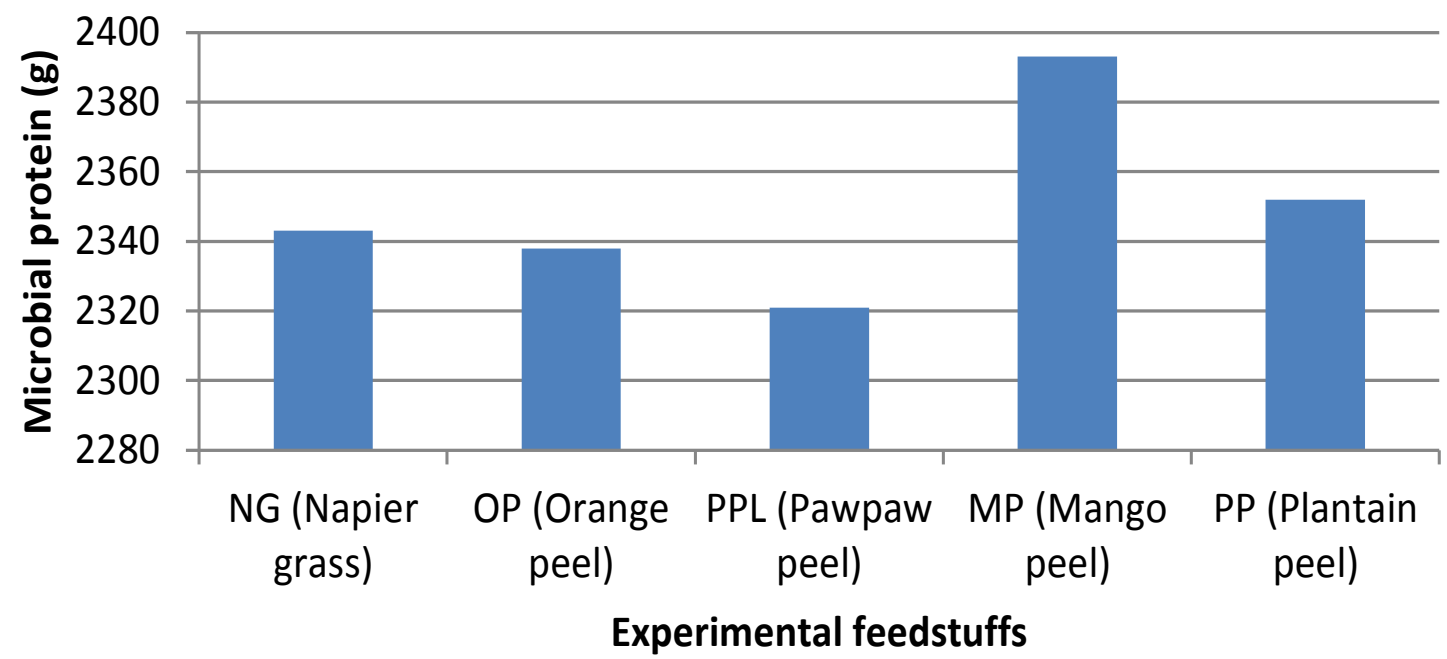

The non significance observed for intercept (a) could probably due to the rate at which the napier grass and fruit peels were soluble in the rumen fluid which were almost at the same time though solubility fraction (b) was significant $(\mathrm{P}<0.05)$ with PPL $(58.98 \mathrm{ml})$ and MP $(53.50 \mathrm{ml})$ being the highest, followed by OP $(41.48 \mathrm{ml})$ and PP $(34.00 \mathrm{ml})$ before NG $(27.00 \mathrm{ml})$ which was the lowest. The observed low NG was expected because of high crude fibre content. This is in line with Akinfemi et al. (2009) who stated that mathematical descriptions of gas production profiles allow analysis of data, evaluation of substrates, fermentability of soluble and slowly fermentable components of feeds. The potential gas production $(\mathrm{a}+\mathrm{b})$ that ranged from 30.00 to $62.00 \mathrm{ml}$ followed a similar pattern of variation as observed in gas production from the insoluble but degradable fraction (b). The highest values were obtained in PPL $(62.00 \mathrm{ml})$ and MP $(58.00 \mathrm{ml})$ while the least was recorded in NG $(30.00 \mathrm{ml})$. The observed low value in NG could be a reflection of low gas production from the insoluble but degradable fraction (b) that result from low microbial activity due to high fibre content. This fact further buttresses arguments against using in vitro fermentation parameters for diets (Aregheare and Abdulrazak, 2005). The rate of gas production (c) values were $0.06(\mathrm{NG}), 0.05(\mathrm{OP}), 0.06$ (PPL), $0.05(\mathrm{MP})$ and $^{0.07 \mathrm{mlh}^{-1}}$ (PP). Though, no significant $(\mathrm{P}>0.05)$ difference was observed, the fastest rate of gas production was observed in PP followed by PPL and NG before OP and MP. This was thought to have been possibly influenced by the soluble carbohydrate fraction readily available to the microbial population in the rumen fluid incubated with the feedstuffs. Cerillo and Juarez (2004), indicated that intake of a feed is mostly explained by the rate of gas production (c) which affects the rumen whereas the potential gas production $(a+b)$ is associated with the degradability of the feed. The incubation time $\left(\mathrm{t}^{1} / 2\right)$ that ranged from 14.65 to 18 hours was significantly $(\mathrm{P}<0.05)$ highest in NG and lowest in MP. This observation indicates that more time was taken by rumen 
microbes to ferment the fiber components in NG compared to fruit peels (PP, OP, PPL and MP, respectively). This is in agreement with the report of Okoruwa et al. (2012) that rumen microbes take longer time to ferment feed with high fibre content than feed with low fibre content.

\section{Organic Matter Degradation, Volatile Fatty Acid Concentration and Estimated Methane Production}

Data on the amount of organic matter degraded, volatile fatty acids (VFA) concentration and estimated methane $\left(\mathrm{CH}_{4}\right)$ production at 24 hours of incubation period are presented in Table 3 . The results showed that the amount of organic matter degraded was significantly $(\mathrm{P}<0.05)$ highest in MP $(42.01 \mathrm{mg})$ and $\mathrm{PP}(40.99 \mathrm{mg})$ followed by PPL (38.76mg) and OP (36.76mg) before NG $(32.04 \mathrm{mg})$ which was the lowest. The observed variation in values of organic matter degraded were inversely correspondent to the fibre content examined in Table 1. This clearly showed that the structural differences in the cell wall of the napier grass and fruit peels, would have significantly $(\mathrm{P}<0.05)$ influenced the extent of difference in the amount of organic matter degraded by rumen microbes. These results were similar to the findings of Kariuki et al. (2001) and Widiawati and Thalib (2009) who reported that cell wall fraction of napier grass is degraded slowly in the rumen fluid and more resistant to rumen microbial degradation when lignification occurs. This also corroborate with the earlier report of Akinfemi et al. (2009) that cell wall of fruit peels usually do not undergo lignification as it occurs in cell wall of grasses. Thus the fruit peels samples are easier to be degraded by rumen microorganisms compared to the napier grass. Moreover, the organic matter degradation values obtained in this study were most within the range values ( 38.00 to $40.00 \mathrm{mg}$ ) reported for napier grass and shrub legume leaves by Widiawati and Thalib (2009).

The universal end-product anaerobic microbial fermentation of carbohydrates in the rumen of ruminants has been reported (Camero and Franco, 2001) to be volatile fatty acids, carbon dioxide and methane. Several reports (Chandaramoni et al., 2002 and Aregheore and Abdulrazak, 2005) also indicated that volatile fatty acids are waste to rumen microbe but valuable to ruminant as the major source of energy in their rations and the most important of these volatile fatty acids in terms of amount produced are acetic, propionic and butyric in that order. However, the values for volatile fatty acid concentration obtained in this study were 48.54, 50.10, 70.92, 72.75 and $71.22 \mathrm{mmol} /$ litre for NG, OP, PPL, MP and PP respectively. Volatile fatty acid values was significantly $(\mathrm{P}<0.05)$ affected at 24 hours of incubation period with MP, PP, PPL and OP being higher than NG. This observed volatile fatty acid pattern of variation between napier grass and fruit peels could probably be an indication of the rapid rate of fermentation from water soluble fractions containing starch and soluble carbohydrates together with the more easily accessible and degradable cellulose. The low volatile fatty acid concentrate value recorded in NG that corroborated with low organic matter degraded in NG could be due to high fibre content in NG compared to fruit peels. This agrees with the report of Dung et al. (2011) who reported that, even though volatile fatty acids contribute about $70 \%$ the caloric requirement of ruminants, the amount of fibre in their diets undoubtedly affects the amount of volatile fatty production in the rumen. The values of volatile fatty acids concentration in the present study compared favourably with the range values (65.00 to 74.70mmol/litre) previously reported by Dung et al. (2011).

It is estimated that up to $80 \%$ of the digestible carbohydrate portion of ruminant rations may be converted to volatile fatty acids inform of acetate, propionate and butyrate which are absorbed directly from the rumen to be metabolized and used as energy in meeting maintenance requirements or stored as fat (Chandaramoni et al., 2002). The molar proportions of the three main volatile fatty acids (acetate, propionate and butyrate) had significant differences $(\mathrm{P}<0.05)$ between napier grass and fruit peels. Acetate was significantly $(\mathrm{P}<0.05)$ higher in NG $(74.42 \%)$ compared to OP $(68.93 \%)$, MP $(67.52 \%)$, PP $(66.23 \%)$ and PPL $(65.90 \%)$. Unlike propionate that was significantly higher $(\mathrm{P}<0.05)$ in PPL $(13.42 \%)$, PP $(13.09 \%)$, MP $(12.66 \%)$ and OP $(10.62 \%)$ compared with NG $(9.35 \%)$. These values showed an apparent inverse relationship between the molar proportion of acetate and propionate for napier grass and fruit peels. This could further explain the presence of high fibre content and lipogenic in napier grass compared to fruit peels. Widiawati and Thalib (2009) reported that fermentation of high fibre content in a diet will result in higher proportion of acetate concentration and $\mathrm{CO}_{2}$ released. The molar proportion of butyrate almost followed the same pattern of variation as observed in propionate. The values of butyrate ranged from 6.43 to $10.20 \%$ with MP, PP and PPL being significantly $(\mathrm{P}<0.05)$ highest followed by OP and then NG which was the lowest. The high proportion of propionate and butyrate concentration obtained in fruit peels might be as a result of high organic matter degradation observed in fruit peels, while low propionate in the incubation of NG could restrain ruminant productivity as propionate has been reported to be the major glycogenic fatty acid in ruminants (Lindela and Lewis, 1995). Researchers (Kariuki et al., 2001 and Widiawati and Thalib, 2009) have reported that if the level of acetic acid resulting from the fermentation of carbohydrate in the rumen can be reduced while the level of propionic acid is increased, the energy of the ruminant ration will be more efficiently used. This shift of the acetic to propionic acid ratio in favour of propionic acid reduce the energy losses that occur in metabolism at the 
cellular level. The molar proportion of volatile fatty acids values obtained in this study were higher than those obtained by Widiawati and Thalib (2009) using napier grass and shrub legume leaves.

Methane gas is an important gas among gases produced by ruminants during fermentation which have negative correlation with energy utilization in ruminants (Babayemi and Bamikole, 2006). Cottle et al. (2011) also reported that methane gas does not only have important implication in relation to the efficiency of energy utilization by ruminants but also to the greater environmental issue in which it is estimated that about $16 \%$ of total methane is released to the atmosphere. The estimated methane values $38.00,36.00,34.00,35.00$ and 35.02 mmol were obtained for NG, OP, PPL, MP and PP respectively. It is noteworthy that the methane value observed in NG was significantly $(\mathrm{P}<0.05)$ higher compared to those obtained in fruit peels (OP, PPL, MP and $\mathrm{PP})$. This would have been expected since the fermentation of NG gives a higher rate of carbon dioxide production which in the presence of hydrogen formed methane. However, the net hydrogen produced that would have been disposed of carbon dioxide in methane by the methanogenic bacteria would have been generated through acetate and butyrate production (Baker, 1999). This fact was also explained by McDonald et al. (2002) that feeds resulting in increase of acetate and carbon dioxide production would promote an increase of methane production, which would represent a net loss of feed energy as well as inefficiency in feed utilization.

\section{Microbial Protein}

Figure I, shows the estimated values of microbial protein produced from napier grass and fruit peels fermented at 24 hours incubation period. The estimated amount of microbial cells synthesized was highest for MP (2393g) followed by PP (2352g) before NG (2343g), OP (2338g) and PPL (2352g). These amount of microbial cells from MP and PP that remained relatively highest at 24 hours of incubation, might be explained by the observation that there were matching increase in volatile fatty acids and consistent pattern of organic matter degradation (Table 3) in these MP and PP to provide appropriate ammonia nitrogen ratio volatile fatty acids ratio for optimum microbial growth. This observation was in conformity with the report of Widiawati and Thalib (2009) that the microbial cells synthesized depend on the value of ammonia nitrogen and volatile fatty acids in the rumen of ruminant animals.

However, microbial growth on NG appeared to have outstripped microbial growth on OP and PPL. This could probably be due to the difference in the balance between ammonia nitrogen and energy derived from volatile fatty acids, though ammonia nitrogen concentration was not determined in this study.

\section{Conclusion}

Based on the results obtained in this study, it can be concluded that fruit peels improve efficiency in rumen fermentation in terms of in vitro gas production, amount of organic matter degraded, volatile fatty acids and microbial protein, but reduced environmental implication were however more pronounced without an adverse effect on Mango Peel (MP) and Plantain Peel (PP) fermented at 24 hours incubation period.

\section{References}

[1]. Adeyosoye, O.I., Adesokan, I.A., Afolabi, K.D. and Ekeocha, A.H. (2010). Estimation of proximate composition and biogas production from in vitro gas fermentation of sweet potato (Ipomea batatas) and wild cocoyam (Colocasia esculenta) peels. African J. Environ. Sci. and Tech., 4(6): 388-391.

[2]. Akinfemi, A., A.O. Adesanya and Aya, V.E. (2009). Use of an in vitro gas production techniques to evaluate some Nigerian feedstuffs. American-Eurasian Journal of Scientific Research, 4(4): 240-245.

[3]. AOAC (1990). Official Methods of Analysis. Association of Official Analytical Chemists, 14th Edition, Washington DC, Pp. 141.

[4]. Aregheare, E.M. and Abdulrazak, S.A. (2005). Estimation of organic matter digestibility and metabolizable energy content of agroindustrial wastes using in vitro gas production. Nig. J. Anim. Prod., 31(1): 79-87.

[5]. Babayemi, O.J. and M.A. Bamikole, (2006). Effect of Tephrosia candida DC leaf and its mixtures with guinea grass on in vitro fermentation changes as feed for ruminants in Nigeria. Pakistan J. Nutri., 5(1): 14-18.

[6]. Bayble, T., Melaku, S. and Prasad, N.K. (2007). Effect of cutting dates on nutritive value of napier (Pennisetum purpureum) grass planted sole and in association with Desmodium (Desmodium intortum) or Lablab (Lablab purpureus). Livestock Research for Rural Development, 19(1): 120-136.

[7]. Bengaly, K.S. Mhlongo and I. V. Nasahlai (2007). The effect of Wattle tannin on intake, digestibility nitrogen retention and growth performance of goats in South Africa. Liv. Res. Rural Dev.19 (4). http://www.cipav.org.co/llrd/19/4/cont 1904.htm.

[8]. Camero, A. and Franco, M. (2001). Improving rumen fermentation and milk production with legume-tree fodder in the tropics. $J$. Agroforestry Sys., 51:157-166.

[9]. Cerillo, M.A. and Juarez, R.A.S. (2004). In vitro gas production parameters in cacti and tree species commonly consumed by grazing goats in a semi arid region of North Mexico. Livestock Research for Rural Development, 16(4), 16021.

[10]. Chandaramoni, C.M.T., Haque, N.M, Murari-Lal, Jadhao, S.B. and Khan, M.Y. (2002). Energy balance in faunated and defaunted sheep on a ratio high in concentration to roughage (good quality) ratio. Pakistan J. Nut., 1:31-33.

[11]. Cottle, D. I., I. V. Nolan and S. G. Wiedemann (2011). Ruminant enteric methane mitigation: a review. Animal production science, 51:491- 514 .

[12]. Dung, D.D., I.R. Godwin and J.V. Nolan (2011). Intake digestibility and rumen parameters of sheep fed commercial pellets or supplemented with Barley grain, or freeze-dried barley sprouts or fresh barley sprouts. Proc. $36^{\text {th }}$ conf. Nig. Soc. For Anim. Prod. Univ of Abuja, Nigeria. Pg $526-528$. 
[13]. Helal, A., Hashem, A.L.S., Abdel-Fattah, M.S. and El-Shaer, H.M. (2010). Effect of heat stress on coat characteristics and physiological responses of Bulady and Damascus goasts in Sinai, Egypt. American Eurasian J. Agric. and Environ. Sci., 7(1): 6069.

[14]. Hegarty, R. S., D. Alcock, D. L. Robinson, J.P. Goopy and P. E. Vercoe (2010). Nutritional and flock Management options to reduce methane output and methane per unit product from sheep enterprises. Animal production science, 50: 1026 - 1033.

[15]. Kariuki, J.N., Tamminga, S., Byachuiri, C.K., Gitau, G.K. and Muia, J.M.K. (2001). Intake and rumen degradation in cattle fed napier grass (Pennisetum purpureum) supplemented with various levels of Desmodium intortum and Ipomoea batatas vines. South African J. Anim. Sci., 31:149-157.

[16]. Lamidi, A.A., Aina, A.B.J. and Sowande, S.O. (2010). Nutrient digestibility and nitrogen balance in West African dwarf goats fed blended diets for dry season. Proc. 35th Conf. Nig. Soc. for Anim. Prod. University of Ibadan, Nigeria. Pg. 499-501.

[17]. McDonald, P., Edwards, R.A., Greenhalgh, J.D. and Morgan, C.A. (2002). Animal nutrition, 6th Edition. United Kingdom, Longman. Pp. 607.

[18]. Menk, K.H. and Steingass, H. (1988). Estimation of the energetic feed value from chemical analysis and in vitro gas production using rumen fluid. Animal Research and Development, 28: 47-55.

[19]. Okoruwa, M.I., Igene, F.U. and Isika, M.A. (2012). Replacement value of cassava peels with rice husk for guinea grass in the diet of West African dwarf sheep. J. Agric. Sci., 4(7): 254 - 261.

[20]. Omole, A.J., Ayodeji, I.O. and Raji, M.A. (2004). The potential of peels of mango, plantain, cocoyam and pawpaw as diets for growing snails (Archachatina marginata). Livestock Research for Rural Development, 16(12): 212-243.

[21]. SAS (1999). Statistical Analysis System. SAS User’s Guide. NY, Cary: SAS Institute.

[22]. Van Soest, P.J., Robertson, J.B. and Lewis, B.A. (1991). Methods for dietary fibre, neutral detergent fibre and non-starch polysaccharide in relation to animal nutrition. J. Dairy Sci., 74: 3583-3597.

[23]. Vasta, V., Mele, N., Serra, A., Scerra, M., Luciano, G., Laniza, M. (2009). Metabolic fate of fatty acids involved in ruminal biohydrogenation in sheep fed concentrate or herbage with or without tannins. J. Anim. Sci., 87: 2674-2684.

[24]. Widiawati, Y. and Thalib, A. (2009). Comparison of fermentation kinetics (in vitro) of grass and shrub legume leaves: The pattern of VFA concentration, estimated $\mathrm{CH}_{4}$ and microbial biomass production. Indonesian Journal of Agriculture 2(1): 21-27.

[25]. Yakubu, A., Raji, A.O. and Omoje, J.N. (2010). Genetic and phenotypic differentiation of qualitative traits in Nigerian indigenous goat and sheep populations. Asia Research Publishing Network (ARPN). Journal of Agricultural and Biological Science. 5(2): 5866. 